\title{
Comparative Study on the Specificities of Several Fungal Aspartic and Acidic Proteinases towards the Tetradecapeptide of a Renin Substrate
}

\author{
Eiji Majima, ${ }^{*}$ Kohei Oda, ** Sawao Murao*** \\ and Eiji ICHISHIMA ${ }^{\dagger}$ \\ Department of Agricultural Chemistry, Faculty of Agriculture, Tohoku University, \\ 1-1, Tsutsumidori-Amamiyamachi, Sendai 980, Japan \\ * Laboratory of Enzymology and Microbial Chemistry, \\ Tokyo University of Agriculture and Technology, \\ Fuchu, Tokyo 183, Japan \\ ** Department of Agricultural Chemistry, University of Osaka Prefecture, \\ Sakai, Osaka 591, Japan \\ *** Department of Applied Microbial Technology, \\ The Kumamoto Institute of Technology, \\ Ikeda, Kumamoto 860, Japan \\ Received October 9, 1987
}

\begin{abstract}
The tetradecapeptide of a renin substrate, DRVYIHPFHLLVYS, was used as a substrate for assaying several fungal aspartic and acidic proteinases in the acidic $\mathrm{pH}$ range. Aspartic and acidic proteinases from Phycomycetes, Mucor and Rhizopus, and Deuteromycotina, Aspergillus and Penicillium, cleaved the tetradecapeptide at its tyrosy $1^{4}$-isoleucyl ${ }^{5}\left(\mathrm{Y}^{4}-\mathrm{I}^{5}\right)$, histidyl ${ }^{6}$-prolyl ${ }^{7}\left(\mathrm{H}^{6}-\mathrm{P}^{7}\right)$ and leucyl ${ }^{11}$-valyl ${ }^{12}\left(\mathrm{~L}^{11}-\mathrm{V}^{12}\right)$ bonds in the acidic $\mathrm{pH}$ range, while acidic proteinases type $\mathrm{B}$ and type A-I from Scytalidium lignicolumn, and those from Cladosporium and Basidiomycetes, Pycnoporus sanguineus, and the yeast, Rhodotorula glutinis, showed slightly different specificities towards the tetradecapeptide. Pepsin primarily cleaved the valy $1^{3}$-tyrosy $]^{4}\left(\mathrm{~V}^{3}-\mathrm{Y}^{4}\right)$ and leucy $1^{10}$-leucy ${ }^{11}\left(\mathrm{~L}^{10}\right.$ $\mathrm{L}^{11}$ ) bonds. All of the aspartic and acidic proteinases of fungal origin tested in the present study have different specificities from that of pepsin.
\end{abstract}

Of the aspartic proteinases, pepsin (EC 3.4.23.1) acts on hemoglobin and the synthetic substrate, acetyl-L-phenylalanyl-diiodotyrosine (Ac-FY- $\left.\mathrm{I}_{2}\right)^{1}{ }^{1}$ ' Pepsin exhibits a milkclotting action at $\mathrm{pH}$ 5.3. While the aspartic proteinase from Aspergillus saitoi (EC 3.4.23.6) does not hydrolyze Ac-FY-I $\mathrm{I}_{2}$, it is capable of activating trypsinogen and chymotrypsinogen in the acidic $\mathrm{pH}$ range. ${ }^{2)}$ The proteinase was inactive as to the milk colotting. The digestion of oxidized insulin B-chain by the Aspergillus aspartic proteinase is not similar to that in the case of human pepsin 5, human pepsin 3 and porcine pepsin C, but is similar to that in the case of cathepsin D (EC
3.4.23.5) from human erythrocytes. ${ }^{3,4)}$ In the previous study, ${ }^{5}$ preparations of Aspergillus aspartic proteinase and Scytalidium lignicolumn acidic proteinase $\mathrm{B}$ were shown to cleave the $\mathrm{H}^{6}-\mathrm{P}^{7}$ bond of proangiotensin (formerly designated as angiotensin I) at $\mathrm{pH} 3.0$ and 2.2, respectively. An additional cleavage site of proangiotensin for the two aspartic and acidic proteinases was the $\mathrm{Y}^{4}-\mathrm{I}^{5}$ bond. On the other hand, pepsin slightly hydrolyzed the valyl $^{3}$-tyrosyl ${ }^{4}\left(V^{3}-Y^{4}\right)$ bond.

The tetradecapeptide, DRVYIHPFHLLVYS, is a specific substrate used for the determination of renin (EC 3.4.23.15) activity. ${ }^{5}$ ) The cleavage site of renin is the leucy $1^{10}$ -

$\dagger$ To whom correspondence should be addressed. 
leucyl ${ }^{11}\left(\mathrm{~L}^{10}-\mathrm{L}^{11}\right)$ bond. In the present study, we expected that the tetradecapeptide would be a useful substrate for proteinases instead of the oxidized insulin B-chain.

\section{MATERIALS AND METHODS}

Materials. The tetradecapeptide (Lot 260116), proangiotensin (Lot 310209) and angiotensin (Lot 260116) were purchased from Peptide Institute Inc., Ina, Mino-shi, Osaka. Dansyl (DMS) chloride was obtained from Tokyo Kasei Kogyo Co., Ltd. The polyamide sheets were from Seikagaku Biochemicals, Tokyo.

The crude enzyme preparations of Aspergillus oryze No. 406, Aspergillus sojae $\mathrm{KS}$ and Penicillium duponti $\mathrm{K}-1014$ were kind gifts from Dr. H. Motai of Kikkoman Co., Ltd., Noda. Mucor racemosus No 50 was a gift from Dr. K. Ahiko of Snow Brand Co., Ltd., Kawagoe. The newlase preparation of Rhizopus sp. was a gift from Dr. H. Tanaka of Amano Pharmaceutical Co., Nagoya.

Crystalline porcine pepsin was purchased from General Biochemical Inc. (Lot 3036). Bovine spleen cathepsin D was obtained from Sigma (Lot 26C-8100).

Aspartic and acidic proteinases. Purification of the Aspergillus oryzae aspartic proteinase was performed by the method of Davidson et al. ${ }^{7)}$ Further purification of the proteinase was performed by the isoelectric focusing method described. Protein was determined from the absorbance at $280 \mathrm{~nm}\left(E_{1 \mathrm{~cm}}^{1 \%}=16.0\right){ }^{7)}$ Purification of the Aspergillus sojae aspartic proteinase I was performed by the method described previously. ${ }^{4)}$ Purification of the Aspergillus saito $i$ aspartic proteinase was performed by a previously described method. ${ }^{3{ }^{38}}$ Protein was determined from the absorbance at $280 \mathrm{~nm}\left(E_{1 \% \mathrm{~cm}}^{1 \%}=13.15\right),{ }^{2)}$

Purification of the Penicillium duponti acidic proteinase was performed by the method of Hashimoto et al..$^{9 j}$ Protein was determined from the absorbance at $280 \mathrm{~nm}$ $\left(E_{1 \mathrm{~cm}}^{1 \%}=11.45\right){ }^{10)}$

Purification of the acidic proteinase from Mucor racemosus No. 50 was performed according to a previous paper. ${ }^{11}$ Purification of the aspartic proteinase from Rhizopus sp. was performed according to a previous paper. ${ }^{12)}$ Protein was determined from the absorbance at $280 \mathrm{~nm}\left(E_{1 \mathrm{~cm}}^{\mathrm{I} \%}=12.9\right){ }^{12)}$

Purification of acidic proteinases type B and type A-1 from Scytalidium lignicolumn was performed as described in a previous paper. ${ }^{13)}$ Protein was estimated from the absorbance at $280 \mathrm{~nm}\left(E_{\mathrm{acm}}^{1 \%}=11.0\right) .{ }^{14)}$

Purification of the acidic proteinase from Pycnoporus sanguineus (formerly designated as Trametes sanguinea or Pycnoporus coccineus) was performed according to a previous paper. ${ }^{15)}$ Protein was determined from the absorbance at $280 \mathrm{~nm}\left(E_{1 \mathrm{~cm}}^{\mathrm{t} \%}=15.0\right)$. Purification of the Cladosporium sp. acidic proteinase was performed accord- ing to a previous paper. ${ }^{16)}$ Protein was determined from the absorbance at $280 \mathrm{~nm}\left(E_{1 \mathrm{~cm}}^{1 \%}=11.7\right) .{ }^{17)}$ Purification of the acidic proteinase from the yeast, Rhodotorura glutinis K-24 was performed as previously described. ${ }^{18)}$ Protein was estimated from the absorbance at $280 \mathrm{~nm}\left(E_{1 \mathrm{~cm}}^{1 \%}=\right.$ 14.0). ${ }^{19}$

Purification of pepsin was performed according to a previous paper by Kaiser and Nakagawa. ${ }^{20)}$ The protein concentration in the case of porcine pepsin was determined from the absorbance at $280 \mathrm{~nm}\left(E_{1 \mathrm{~cm}}^{1 \%}=14.1\right){ }^{21}$, Bovine spleen cathepsin D was used without further purification.

Separation and identification of peptides from the digests of the tetradecapeptide, proangiotensin and angiotensin. The tetradecapeptide $(1.14 \mu \mathrm{mol}, 2 \mathrm{mg}), \quad$ proangiotensin $(1.54 \mu \mathrm{mol}, 2 \mathrm{mg})$ or angiotensin $(1.91 \mu \mathrm{mol}, 2 \mathrm{mg})$ was dissolved in $10 \mathrm{ml}$ of dilute $\mathrm{HCl}, 8 \mathrm{nkatal}$ of an aspartic or acidic proteinase was added to the solution, and then the $\mathrm{pH}$ was adjusted to $\mathrm{pH} 2.2 \sim 3.2$ with dilute $\mathrm{HCl}$. Each mixture was incubated at $30^{\circ} \mathrm{C}$ for $3 \mathrm{hr}$. A few drops of concentrated $\mathrm{NH}_{4} \mathrm{OH}$ were added to inactivate the enzyme. Samples of the hydrolysate were cooled to $-20^{\circ}$, and then the frozen digest was lyophilized.

The freeze-dried digest was then dissolved in $100 \mu$ l of $1 \mathrm{M} \mathrm{NH}_{4} \mathrm{OH}$ and then separated on Toyo filter paper, in the first dimension, by high voltage paper electrophoresis in pyridine-acetic acid-water, 10:0.4:90 (v/v), at pH 6.5 for $150 \mathrm{~min}$ at $45 \mathrm{~V} / \mathrm{cm}$. After drying at room temperature, ascending chromatography was carried out with a solvent system of $n$-butanol-acetic acid-water, $4: 1: 2(\mathrm{v} / \mathrm{v})$, for $60 \mathrm{hr}$. The peptide maps were stained with 0.02 or $0.2 \%$ ninhydrinacetone reagent and $0.1 \% p$-nitrobenzene sulfonic acid solution (Paury's reagent). Ninhydrin positive zones and Paury's reagent positive zones were cut out from the sheet and then the peptides were washed with acetone and then eluted with water. The eluates were freeze-dried in vacuo.

Amino acid analysis. Freeze-dried peptides were dissolved in $2 \mathrm{ml}$ of $6 \mathrm{M} \mathrm{HCl}$ and then hydrolyzed at $110^{\circ} \mathrm{C}$ for $24 \mathrm{hr}$. Hydrolysates of peptides were examined with a Hitachi amino acid analyzer, model KLA-3A or 835-30.

Determination of $N$-terminal amino acids of the peptides. The $\mathrm{N}$-terminal amino acids of the purified peptides were determined by the DNS-method. ${ }^{22)}$

Determination of C-terminal amino acids of the peptides. The release of. the C-terminal amino acids from the peptides was performed using Penicillium janthinellum acid carboxypeptidase ${ }^{23,24)}$ at $\mathrm{pH} 3.7$ and $30^{\circ} \mathrm{C}$. The enzyme is now commercially available from Peptide Institute, Inc., Ina, Mino-shi, Osaka (Code 3502)

Estimation of the extents of hydrolysis of the various peptide bonds. The extents of hydrolysis of the individual 
peptide bonds which were split were then calculated by summation of the yields of the peptides located on either side of each opened bond.

\section{RESULTS}

Figure 1 is a summary of the specificities of the aspartic proteinase from Aspergillus oryzae towards angiotensin, proangiotensin and the tetradecapeptide of a renin substrate at $\mathrm{pH} 3.0$ and $30^{\circ} \mathrm{C}$ on $3 \mathrm{hr}$-hydrolysis. The results show that the $\mathrm{Y}^{4}-\mathrm{I}^{5}$ bonds in angiotensin, proangiotensin and the tetradecapeptide were easily hydrolyzed. Although the $\mathrm{H}^{6}-\mathrm{P}^{7}$ bond is not a usual peptide bond, enzymatic hydrolysates of the $\mathrm{H}^{6}-\mathrm{P}^{7}$ bonds of proangiotensin and the tetradecapeptide was observed, and two peptides from each $\left(\mathrm{I}^{5} \mathrm{H}^{6}\right.$ and $\mathrm{P}^{7} \mathrm{FHL}^{10}$, and $\mathrm{I}^{5} \mathrm{H}^{6}$ and $\mathrm{P}^{7} \mathrm{FHLL}{ }^{11}$ ) were obtained with the aspartic proteinase from Aspergillus oryzae. The extent of hydrolysis of the $\mathrm{H}^{6}-\mathrm{P}^{7}$ bond was about $50 \sim 60 \%$ of that of the $\mathrm{Y}^{4}-\mathrm{I}^{5}$ bond. The aspartic proteinase from Aspergillus oryzae could not split the $\mathrm{H}^{6}-\mathrm{P}^{7}$ bond in angiotensin. This aspartic proteinase also cleaved the $\mathrm{L}^{11}-\mathrm{V}^{12}$ bond in the tetradecapeptide. Thus the aspartic proteinase from Aspergillus oryzae exhibited a lower preference for the $\mathrm{H}^{6}-\mathrm{P}^{7}$ bond than for the $\mathrm{Y}^{4}-\mathrm{I}^{5}$ and $\mathrm{L}^{11}-\mathrm{V}^{12}$ bonds.

Figure 2 shows the specificities of aspartic or acidic proteinases from two species of Pycomycetes, Mucor racemosus and Rhizopus sp., and three species of Deuteromycotina, Aspergillus sojae, Aspergillus saitoi and Penicillium duponti. These aspartic or acidic proteinases hydrolyzed three bonds, $\mathrm{Y}^{4}-\mathrm{I}^{5}, \mathrm{H}^{6}$ $\mathrm{P}^{7}$ and $\mathrm{L}^{11}-\mathrm{V}^{12}$. On hydrolysis by the proteinases from Rhizopus sp. and Penicillum duponti, the relative extents of hydrolysis at $\mathbf{L}^{11}$. $\mathrm{V}^{12}$ were, respectively, 2- and 3-fold greater than that at $\mathrm{Y}^{4}-\mathrm{I}^{5}$. The relative extent of $\mathrm{H}^{6}-\mathrm{P}^{7}$ hydrolysis by the proteinase from Penicillium duponti was great, being about 3-fold greater than that of $\mathrm{Y}^{4}-\mathrm{I}^{5}$ hydrolysis.

Figure 3 shows the specificities of acidic proteinases type B and type A-1 from the Deuteromycotina, Scytalidium lignicolumn,
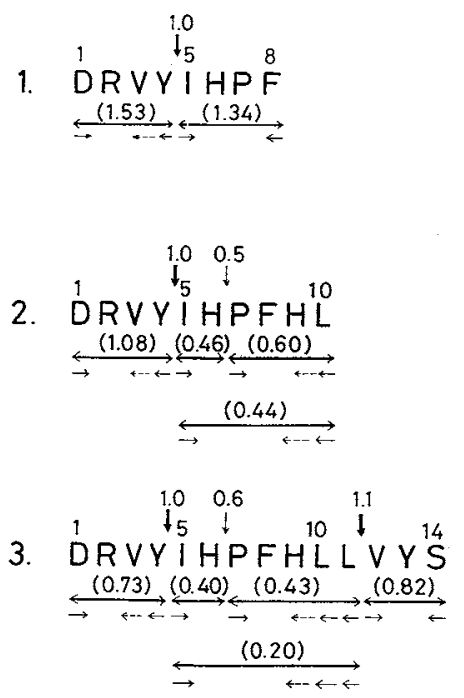

FIG. 1. Summary of the Specificities of the Aspartic Proteinase from Aspargillus oryzae towards Angiotensin, Proangiotensin and the Tetradecapeptide at $\mathrm{pH} 3.0$ and $30^{\circ}$ for $3 \mathrm{hr}$.

Values in parentheses denote the uncorrected recoveries $(\mu \mathrm{mol})$ of peptides. Perpendicular arrows $(\downarrow)$ indicate the bonds split, the degree of hydrolysis being as follows: $\downarrow>\downarrow>\downarrow$. The extent of hydrolysis of the $\mathrm{Y}^{4}-\mathrm{I}^{5}$ bond is arbitrarily taken to be 100 . Horizontal arrows indicate residues recovered with the following procedures: $\rightarrow$ indicated by the DNS method, $\longleftarrow$ amino acid with Penicillium janthinellum acid carboxypeptidase; the degree of hydrolysis being as follows; $\longleftarrow>-. .1$, angioten $\sin \mathrm{e} / \mathrm{s}=$ $1: 13913(\mathrm{~mol} / \mathrm{mol}) ; 2$, proangiotensin $\mathrm{e} / \mathrm{s}=1: 11224(\mathrm{~mol} /$ mol); 3 , the tetradecapeptide e/s $=1: 8272(\mathrm{~mol} / \mathrm{mol})$.

towards the tetradecapeptide at $\mathrm{pH} 2.2$ and 3.2 , respectively. The type $\mathrm{B}$ proteinase clearly hydrolyzed the $\mathrm{H}^{6}-\mathrm{P}^{7}$ and $\mathrm{H}^{9}-\mathrm{L}^{10}$ bonds at similar relative rates. The type $\mathrm{B}$ proteinase showed lower preference for the $\mathrm{Y}^{4}-\mathrm{I}^{5}$ bond. The type A-1 proteinase clearly hydrolyzed the $\mathrm{Y}^{4}-\mathrm{I}^{5}, \mathrm{~F}^{8}-\mathrm{H}^{9}$ and $\mathrm{L}^{10}-\mathrm{L}^{11}$ bonds in the tetradecapeptide at $\mathrm{pH} 3.2$ and $30^{\circ} \mathrm{C}$ for $3 \mathrm{hr}$.

Figure 4 shows the specificities of acidic proteinases from two species of Basidiomycetes, Pycnoporus sanguineus and the yeast, Rhodotorula glutinis, and the yeast-like Deuteromycotina, Cladosporium sp. The acidic proteinase from Cladosporium sp. cleaved $\mathrm{Y}^{4}-\mathrm{I}^{5}$ and $\mathrm{L}^{11}-\mathrm{V}^{12}$ at $\mathrm{pH} 2.5$ and $30^{\circ} \mathrm{C}$ for $3 \mathrm{hr}$. Additional cleavage of the bond $R^{2}-V^{3}$ was noted. The acidic proteinase from Pycnopo- 


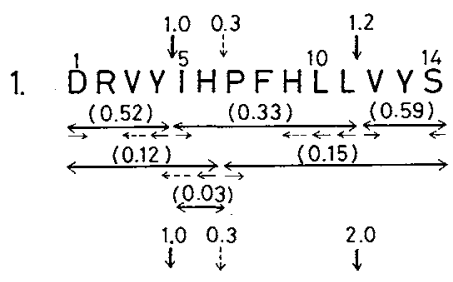

2. DRVYIHPFHLLVYS

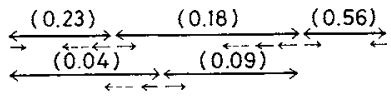
$\begin{array}{lll}1.0 & 0.4 & 1.4 \\ i & i & i\end{array}$

3. DRVYIHPFHLLVYS

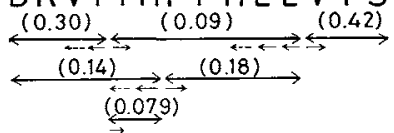

4. DRVYIHPFHLLVYS

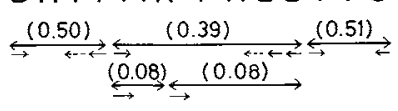

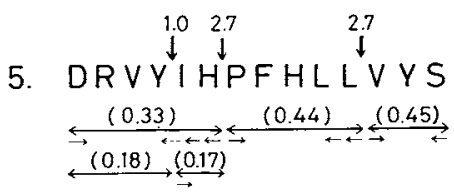

FIG. 2. Summary of the Specificities of the Aspartic or Acidic Proteinases from Two Species of Phycomycetes, Mucor racemosus and Rhizopus sp. and Three Species of Deuteromycotina, Aspergillus sojae, Aspergillus saitoi and Penicilium duponti.

1, Mucor racemosus acidic proteinase, 3-hr incubation at $\mathrm{pH} 3.0, \mathrm{e} / \mathrm{s} 1: 1 \mathrm{I}(\mathrm{w} / \mathrm{w}) ; 2$, Rhizopus sp. aspartic proteinase, 3-hr at $\mathrm{pH} 3.1, \mathrm{e} / \mathrm{s} 1: 172$ (mol/mol); 3, Aspergillus sojae aspartic proteinase, 3-hr incubation at $\mathrm{pH} 3.1$, e/s $1: 172$ (mol/mol); 4, Aspergillus saitoi aspartic proteinase, 3-hr incubation at $\mathrm{pH} 2.7, \mathrm{e} / \mathrm{s} 1: 272(\mathrm{~mol} / \mathrm{mol}) ; 5$, Penicillium duponti acidic proteinase, 3 -hr incubation at $\mathrm{pH} 2.5$, e/s $1: 16(\mathrm{~mol} / \mathrm{mol})$.

rus sanguineus clearly hydrolyzed the $\mathrm{Y}^{4}-\mathrm{I}^{5}$ and $\mathrm{L}^{11}-\mathrm{V}^{12}$ bonds at $\mathrm{pH} 2.7$ and $30^{\circ} \mathrm{C}$ for $3 \mathrm{hr}$. That from Rhotorula glutinis hydrolyzed the $\mathrm{Y}^{4}-\mathrm{I}^{5}$ and $\mathrm{L}^{11}-\mathrm{V}^{12}$ bonds at $\mathrm{pH} 2.5$ and $30^{\circ} \mathrm{C}$ for $3 \mathrm{hr}$. Additionai cleavage of the $\mathrm{V}^{3}-\mathrm{Y}^{4}$ and $\mathrm{L}^{10}-\mathrm{L}^{11}$ bonds was also noted.

Figure 5 shows the specificities of porcine pepsin towards the tetradecapeptide at $\mathrm{pH} 2.0$ and $30^{\circ} \mathrm{C}$ for $72 \mathrm{hr}$. Pepsin cleaved the $\mathrm{V}^{3}-\mathrm{Y}^{4}$ and $\mathrm{L}^{10}-\mathrm{L}^{11}$ bonds. Additional cleavage of the $\mathrm{Y}^{4}-\mathrm{I}^{5}$ and $\mathrm{V}^{12}-\mathrm{Y}^{13}$ bonds was noted. Pepsin

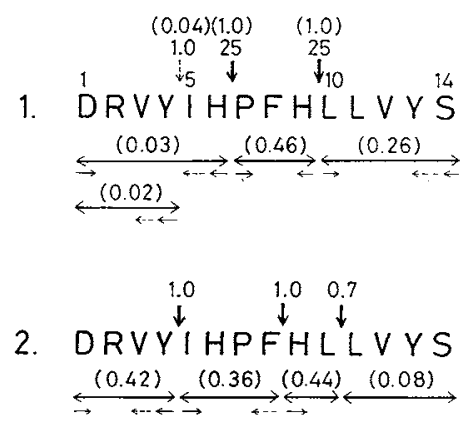

FIG. 3. Specificities of Acidic Proteinases Type B and Type A-1 from Scytalidium lignicolumn.

1, type B proteinase, 3-hr incubation at $\mathrm{pH} 2.3$ and $30^{\circ} \mathrm{C}$, $\mathrm{e} / \mathrm{s} 1: 72(\mathrm{~mol} / \mathrm{mol}) ; 2$, type A-1 proteinase, $3-\mathrm{hr}$ incubation at $\mathrm{pH} 3.2$ and $30^{\circ} \mathrm{C}, \mathrm{e} / \mathrm{s} 1: 251(\mathrm{~mol} / \mathrm{mol})$.



FIG. 4. Summary of the Specificities of the Acidic Proteinases from Two Species of Basidiomycetes, Pycnoporus sanguinesu and the Yeast, Rhodotolura glutinis, and the Yeast-like Deuteromycotina, Cladosporium sp.

1, Cladosporium sp. acidic proteinase, 3-hr incubation at $\mathrm{pH} 2.5, \mathrm{e} / \mathrm{s} 1: 165$ (mol/mol); 2, Pycnoporus sanguineus acidic proteinase, 3-hr incubation at $\mathrm{pH} 2.7$, e/s 1:54 (mol/mol); 3, Rhodotorula glutinis acidic proteinase, 3-hr incubation at $\mathrm{pH} 2.5, \mathrm{e} / \mathrm{s} 1: 104(\mathrm{~mol} / \mathrm{mol})$.

has a different and characteristic specificity compared with fungal aspartic proteinases, but has no ability to hydrolyze the $\mathrm{H}^{6}-\mathrm{P}^{7}$ bond in the tetradecapeptide. Bovine spleen cathepsin D (EC 3.4.23.5) slightly hydrolyzed the $\mathrm{Y}^{4}-\mathrm{I}^{5}$ and $\mathrm{F}^{8}-\mathrm{H}^{9}$ bonds in proangiotensin at $\mathrm{pH} 3.0$ 


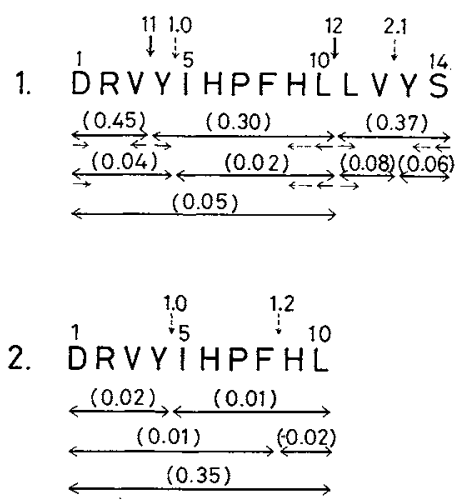

FIG. 5. Summaries of the Specificities of Porcine Pepsin and Spleen Cathepsin D.

1, pepsin, 72-hr incubation at pH 2.0 and $30^{\circ} \mathrm{C}, \mathrm{e} / \mathrm{s} 1: 96$ ( $\mathrm{mol} / \mathrm{mol}$ ); 2, cathepsin D, 72-hr incubation at $\mathrm{pH} 3.0$ and $30^{\circ} \mathrm{C}, \mathrm{e} / \mathrm{s} 1: 161(\mathrm{~mol} / \mathrm{mol})$.

and $30^{\circ} \mathrm{C}$ for $72 \mathrm{hr}$ with an enzyme substrate ratio of $1: 200 \mathrm{~mol} / \mathrm{mol}$ (Fig. 5). Although four peptides $\left(\mathrm{D}^{1} \mathrm{RVY}^{4}, \mathrm{I}^{5} \mathrm{HPFHL}^{10}\right.$, $\mathrm{D}^{1} \mathrm{RVYIHPF}^{8}$ and $\mathrm{H}^{9} \mathrm{~L}^{10}$ ) were obtained through the action of cathepsin $D$, the yields were low.

\section{DISCUSSION}

The aspartic proteinases from Aspergillus $^{25,26)}$ and Penicillium ${ }^{12)}$ have many properties in common with porcine pepsin and, like pepsin, have aspartic acid residues at their active sites. In previous studies, we found that aspartic proteinases from Aspergillus have different specificities towards oxidized insulin B-chain ${ }^{3,4)}$ and proangiotensin, 5) as compared with pepsin. In the present study we confirmed the specificities of the aspartic and acidic proteinases from Aspergillus and of the other fungal origin towards the tetradecapeptide of a renin substrate, which contains 14 amino acid residues with 10 different species.

The aspartic proteinase from Aspergillus oryze could not split the $\mathrm{H}^{6}-\mathrm{P}^{7}$ bond in angiotensin. This suggests that the $\mathrm{P}_{3}^{\prime}$ position may be essential for the hydrolysis by an aspartic proteinase. Furthermore, the aspartic proteinase from Aspergillus could not hydrolyze the $\mathrm{V}^{3}-\mathrm{Y}^{4}$ bonds (Figs. 1 and 2). These results suggest that the $\mathrm{P}_{4}$ position may be essential for the hydrolysis by the aspartic proteinases from Aspergillus. Thus the aspartic proteinases from Aspergillus exhibited a lower preference for small peptides and could not hydrolyze any commercial synthetic peptides. ${ }^{2)}$ All of the aspartic or acidic proteinases from Phycomycetes, Mucor and Rhizopus, and two genera of Deuteromycotina, Aspergilus and Penicillum, clearly hydrolyzed the $\mathrm{H}^{6}-\mathrm{P}^{7}$ bond in the tetradecapeptide. In the enzymatic hydrolysates, the dipeptide, $\mathrm{I}^{5} \mathrm{H}^{6}$, was recovered with aspartic and acidic proteinases from Aspergillus oryzae, Aspergillus sojae, Aspergillis saitoi, Penicillium duponti and Mucor racemosus, as shown in Figs. 1 and 2 . The acidic proteinase from Penicillium duponti showed the highest extent of hydrolysis at the $\mathrm{H}^{6}-\mathrm{P}^{7}$ bond (Fig. 2).

From with the information presented in this paper, it can be concluded that the aspartic or acidic proteinases from Aspergillus, Penicillium, Mucor and Rhizopus have similar specificities, including enzyme-substrate affinity and turnover rate.

The pepstatin-insensitive acidic proteinases, A-1 and B, were products of the Deuteromycotina, Scytalidium lignicolumn. ${ }^{13)}$ The molecular weight of the type A-1 proteinase was found to be 40,000 with $\mathrm{pI}=3.6$, the optimum $\mathrm{pH}$ being $3.0 \sim 3.5$. The molecular weight of the type $\mathrm{B}$ enzyme was found to be 21,969 with $\mathrm{pI}=3.2$, the optimum $\mathrm{pH}$ being 2.2. In the present experiments, the type A-1 proteinase exhibited a preference for a hydrophobic amino acid residue at the $P_{1}$ position. The type $B$ proteinas was shown here to have high affinity for the $\mathrm{H}^{6}-\mathrm{P}^{7}$ and $\mathrm{H}^{9}-\mathrm{L}^{10}$ bonds in the tetradecapeptide $\mathrm{pH}$ 2.2. The type $B$ proteinase exhibited a preference for a hydrophobic amino acid residue at the $\mathrm{P}_{1}^{\prime}$ position and a hydrophilic amino acid residue at the $P_{1}$ position. The two proteinases have different specificities from the others as to tetradecapeptide hydrolysis.

The acidic proteinases from Cladosporium, Rhodotorula glutinis, Rhizopus sp. and Aspergillus were inactivated by Streptomyces 
pepsin inhibitor (S-PI, acetylpepstatin). ${ }^{27)}$ As shown in Fig. 4, the acidic proteinases from two Basidiomycetes, Rhodotorula glutinis and Pycnoporus sanguineus, and the yeast-like Deuteromycotina, Cladosporium sp., could hydrolyze the $\mathrm{Y}^{4}-\mathrm{I}^{5}$ and $\mathrm{L}^{11}-\mathrm{V}^{12}$ bonds, but could not hydrolyze the $\mathrm{H}^{6}-\mathrm{P}^{7}$ bond in the tetradecapeptide, unlike the aspartic and acidic proteinases from Aspergillus, Mucor and Rhizopus.

The present results in Fig. 5 also show that pepsin exhibited a preference for hydrophobic amino acid residues at both the $P_{1}$ and $P_{1}^{\prime}$ positions, the $\mathrm{V}^{3}-\mathrm{Y}^{4}$ and $\mathrm{L}^{10}-\mathrm{L}^{11}$ bonds, in the tetradecapeptide. Pepsin additionally cleaved the $\mathrm{V}^{12}-\mathrm{Y}^{13}$ bond at a low reaction rate. The $\mathrm{P}_{3}^{\prime}$ position may therefore be important for the catalytic efficiency of hydrolysis at the $P_{1}$ $\mathrm{P}_{1}^{\prime}$ bond with pepsin. No synthetic substrate of a defined chemical composition has been found for cathepsin D. Dorer et al. ${ }^{28)}$ reported that cathepsin $D$ only cleaved the $\mathrm{L}^{10}-\mathrm{L}^{11}$ bond in the tetradecapeptide, releasing proangiotensin $\left(\mathrm{D}^{1}-\mathrm{L}^{10}\right)$. In the present study we found a very low hydrolytic activity of cathep$\sin \mathrm{D}$ towards the $\mathrm{Y}^{4}-\mathrm{I}^{5}$ and $\mathrm{F}^{8}-\mathrm{H}^{9}$ bonds in proangiotensin at $\mathrm{pH}$ 3.0. The splitting sites of cathepsin D resembled that of the serine proteinase from Aspergillus sojae. ${ }^{29)}$

It can be concluded that the specificities of all aspartic and acidic proteinases of fungal origin are different from those of animal pepsin and cathepsin D.

Acknowledgments. This work was supported in part by a Grant-in-Aid for Research Council from the Ministry of Agriculture, Forestry and Fisheries of Japan, as an original and creative research project in biotechnology. We wish to thank Mrs. Y. Yokoo for preparation of the figures.

\section{REFERENCES}

1) A. P. Ryle, "Methods of Enzymatic Analysis," ed. by H. U. Berger, Verlag Chemie, Weinheim. Deerfield Beach, Florida Basel, 1970, p. 223.

2) E. Ichishima, "Methods in Enzymology," Vol. XIX, ed. by G. E. Perimann and L. Lorand, Academic Press, New York, 1970, p. 397.

3) N. Tanaka, M. Takeuchi and E. Ichishima,
Biochim. Biophys. Acta, 485, 406 (1977).

4) T. Kimura, Y. Mayumi, M. Takeuchi, K. Hayashi and E. Ichishima, Curr. Microbiol, 3, 153 (1979).

5) E. Ichishima, E. Majima, M. Emi, K. Hayashi and S. Murao, Agric. Biol. Chem., 45, 2391 (1981).

6) T. Inagami and M. Murase, "Methods of Enzymatic Analysis," Vol. V, ed. by H. U. Bergmeyer, Verlag Chemie, Weinheim·Deerfield Beach, Florida Basel, 1984, p. 249.

7) R. Davidson, A. Gertler and T. Hofmann, Biochem. J., 147, 45 (1975).

8) M. Takeuchi and E. Ichishima, Anal. Biochem., 74, 627 (1976).

9) H. Hashimoto, Y. Kaneko, T. Iwaasa and T. Yokotsuka, Appl. Microbiol., 25, 584 (1973).

10) S. Emi, D. V. Myers and G. A. Iacobucci, Biochemistry, 15, 842 (1976).

11) K. Higashio and Y. Yoshioka, Nippon Nōgeikagaku Kaishi, 55, 959 (198I).

12) J. Sodek and T. Hofmann, "Methods in Enzymology," Vol. XIX, ed. by G. E. Perlmann and L. Lorand, Academic Press, New York, 1970, p. 372 .

13) K. Oda and S. Murao, Agric. Biol. Chem., 38, 2435 (1974).

14) K. Oda, S. Murao, T. Oka and K. Morihara, Agric. Biol. Chem., 40, 859 (1976).

15) E. Ichishima, H. Kumagai and K. Tomoda, Curr. Microbiol., 3, 333 (1979).

16) S. Murao, S. Funakoshi and K. Oda, Agric. Biol. Chem., 36, 1327 (1972).

17) K. Oda, S. Funakoshi and S. Murao, Agric. Biol. Chem., 37, 1723 (1973).

18) K. Kamada, K. Oda and S. Murao, Agric. Biol. Chem., 39, 1095 (1972).

19) K. Oda, K. Kamada and S. Murao, Agric. Biol. Chem., 36, 1103 (1972).

20) E. T. Kaiser and Y. Nakagawa, "Acid Protease" in Adv. Exptl. Med. Biol., Vol. 95, ed. by J. Tang, Academic Press, New York, 1977, p. 159.

21) M. M. Meyer and J. A. Miller, Anal. Cham., 36, 91 (1970).

22) G. Winter, "Practical Protein Chemistry-A Handbook," ed. by A. Darbre, John Wiley \& Sons, New York, 1986, p. 367.

23) S. Yokoyama, A. Oobayashi, O. Tanabe and E. Ichishima, Biochim. Biophys. Acta, 397, 443 (1975).

24) S. Yokoyama, A. Oobayashi, O. Tanabe, K. Ohata, Y. Shibata and E. Ichishima, Experientia, 31, 1122 (1975).

25) K. Takahashi and W.-J. Chang, J. Biochem., 73, 675 (1973).

26) K. Takahashi, F. Mizobe and W.-J. Chang, J. Biochem., 71, 161 (1972).

27) S. Murao and K. Oda, "Aspartic Proteinases and Their Inhibitors," ed. by V. Kostka, Walter de Gruyter, Berlin, 1985, p. 379. 
28) F. E. Dorer, K. E. Lentz, J. R. Kahn, M. Levin and L. T. Skeggs, J. Biol. Chem., 253, 3140 (1978).

29) E. Ichishima, M. Hamamatsu, N. Yamamoto, H.
Motai and K. Hayashi, Food Chem., 11, 187 (1983). 